\title{
Susceptibility of Certain Corn Cultivars to Infestation with Two Aphid Species in
} Qalubia Governorate

Mona S. Hassn ${ }^{1}$; El-Khayat, E. F. ${ }^{1}$; Safaa M. Halawa ${ }^{1}$; Tahany R. Abd El-Zaher ${ }^{1}$ and M. F. El- Mitwally ${ }^{2}$

IPlant Protection Department, Faculty of Agriculture, Benha University, Egypt.

${ }^{2}$ Field Crop Pests Research Department, Plant Protection Research Institute, Agricultural Research Centre, Dokki, Giza, Egypt

Corresponding author: Safa.halawa@fagr.bu.edu.eg

\begin{abstract}
Field and laboratory studies were carried out during two successive summer seasons (2016 and 2017) in order to study the susceptibility of the different tested Maize cultivars namely (Giza (2), Single cross (10), and Treble cross (321) to infestation by two species of aphids, Rhopalosiphum maidis and Rhopalosiphum padi. Field studies were carried out during the two consecutive growing seasons (2016 and 2017). There were significant differences in the susceptibility of Maize cultivars to infestation by these pests. Results showed that, G 2 and S.C (10) cultivars were the lowest infested ones by the two pests. On the other hand, T.C (321) variety was the highest infested cultivar. To give a spot light on the reason of the differences in the susceptibility of the tested Maize cultivars, chemical analysis of the dried leaves were carried out during growing season of 2017. Chemical analysis of infested leaves showed correlation between certain phytochemical components; potassium, total protein, carbohydrate, and phosphorous as well as Fiber, Vt B 6 and Vt B 1 content and population density of Rhopalosiphum maidis and Rhopalosiphum padi. A significant difference between the mean count of aphids harbored on leaves of the three tested cultivars was found, as the heaviest infestation was recorded on leaves of T.C321 cultivar (10.6 individuals / leaf) which had the thinnest layers of the upper and lower epidermal cuticle thickness, No. of spongy tissue layers in the blade, spongy tissue thickness in the blade and spongy tissue thickness midrib of leaf. $(9.00,7.20,4.00,324.00$ and $810.00 \mu \mathrm{m}$, respectively.
\end{abstract}

Key words: Maize cultivars, aphid, phytochemical, Anatomy of maize leaves

\section{Introduction}

Maize (Zea mays L.) is one of the most important cereal crops in Egypt and the world. Maize is still a major traditional food and feed crop in many regions. Furthermore, the grain is a key industrial raw material for very diverse purposes. Also, maize enters in the process of manufacturing some important products such as corn oil, fructose and starch .A great attention has been paid to increase its total production. The amount of the Egyptian imports of maize reached to about 4821.2 thousand tons in the average period (2000-2013) at a value reached to about 1032.75 million dollars(Abd el Fatah et al. 2015). The serious pests of which are the larvae of lepidopterous species, including the pink stem borer Sesamia cretica Led. (Hassan, 2012), the Europeam corn borer Ostrinia nubilalis Hubn. (Maini and Burgio 1999) the same importance, corn leaf plants are attacked by homopterous pests that have great economic importance to the crops. They cause serious damage directly by sucking plant sap or indirectly by transmission of virus diseases (ElGindy, 2002 and El-Fatih et al., 2015). Aphids are a group of the most injurious insect pests of legumes and cereals in Egypt (Ismail et al., 1993 and Ali $\boldsymbol{e t}$ al., 2013), sucking the plant nutrients, exuding the harmful honeydew and transmitting diseases to the plant crop leading to reduction of its yield (El-
Defrawi et al., 2000; Ali, 2004; Swaminathan et al., 2016 and Ibraheem et al. 2021).

So, the current investigation was mostly built up to select the lowest infested cultivars with these pests as one of the control options to suppress heavy pests infestations in Integrated Pest Management (I.P.M.) programs and as a result the resistant and susceptible varieties reviewed in the present study is one of the important reasons which have to be add to inheritance as sources of resistance.

\section{Materials and Methods}

The present investigation was carried out at the experimental farm of the Faculty of agriculture, Moshtohor, Benha, university Qaliobia, Governorates during two successive maize growing seasons (2016, and 2017)

1-Susceptibility of different maize cultivars to infestation rate induced by two species of Aphids:

The maize seeds of the three studied cultivars were cultivated in 14 July during the two studied seasons Three Maize cultivars namely (G2), (T.C 321) and (S.C 10) for two successive growing seasons, (2016 and 2017) were planted to study their susceptibility to infestation by Rhopalosphum maidis and Rhopalosiphum padi. The area of the experiment and variety was $630 \mathrm{~m}^{2}$ cultivated by $\mathrm{G} 2$ , TC 321 and SC 10 varieties. This area divided to (15) replicates five replicates for each variety (the 
area / replicate $\left(42 \mathrm{~m}^{2}\right.$. Each plot consisted of 10 rows, 6 meters long and $75 \mathrm{~cm}$ wide. Maize seeds were sown at rate of $3 \mathrm{seed} / \mathrm{hill}$, at $30 \mathrm{~cm}$ distance between the seed beds. Planting date was on July $14^{\text {th, }}$ and all replicates were arranged in a randomized complete block design. Normal Agricultural practices were followed. One week after sowing and for 13 weeks samples of 4 leaves representing from all plant level were collected. Ten plants were randomly taken from each replicate (200 leaves) from each cultivar. The collected leaves were placed directly in paper bags and transferred to laboratory .All stages of aphids were counted.

\section{Phytochemical components of leaves of corn cultivars.}

The aim of this study was to find out the relationship between the leaf-components of the three studied corn cultivars G2, S. C10 and T. C 321 and the rate of Rhopalosphum maidis and Rhopalosiphum padi, infestation throughout the second season, 2017. Leaves samples were collected after 40 days. Leaves of each cultivar were homogenized by Teflon tissue grinder using a glass cup surrounded by ice jacket. Distilled water was used as the homogenizing medium .The homogenate was centrifuged at $8000 \mathrm{rpm}$ for $15 \mathrm{~min}$ using a refrigerated centrifuge. The sediment was discarded and the supernatant was taken for biochemical determination.

2.1. Carbohydrates and total Proteins: were determined according to the methods of Pregl (1945)

2.2. K determination: Ions measurements were made on a radiometer FLM3 flame photometer as described by Amin and ELHalafawy (2001).

2.3. Phosphorus (P) content was determined according to method of Troug and Meyer (1939)

3. Anatomical characters of corn cultivars leave:

This experiment was carried out to explain the relationship between anatomical character of leaves of the previously mentioned corn cultivars G2, S. C10 and T.C321 and infestation rates with Ropalosiphum midis and Rhopalosiphum padi. Anatomical characters of leaves were studied by using the methods described by Jackson (1970). Samples of each cultivar Leaves were picked and fixed in FAA solution (10ml formalin $+5 \mathrm{ml}$ glacial acid $+85 \mathrm{ml}$ ethyl alcohol $70 \%$ ). After that transverse section in the leaves were made. The different measurements (in micron um) of the thickness of cuticle layer, thickness of epidermis Layer, thickness of central tissue (palisade tissue and spongy tissue), were determined at department of Agricultural plants in Faculty of Agriculture Moshtohor, Benha University.
The collected data were subjected to proper statistical analysis of (F) test according to Fisher (1954), to compare between means L.S.D at .0.05 level of probability was used according to Waller and Duncan (1969).

\section{Results and Discussion}

\section{1-Susceptibility of different maize cultivars to infestation of some Aphids species.}

The aim of this study is to determine the susceptibility of three maize cultivars G2, S.C 10 and T.C321 to aphids infestation during two successive season 2016 and 2017.

1.1. Susceptibility of different maize cultivars to infestation with (Rhopalosphum maidis) during 2016 and 2017 seasons in Qalubia Governorate.

Data obtained in Table (1) and Fig.(1) showed that the infestation percent with aphids was differed significantly according to the tested cultivars. In the first season 2016 a significant high infestation by Rhopalosphum maidis aphid population was recorded on T.C 321 cultivar with seasonal total numbers of 113.2 individuals/leaf followed with 83.3 for S.C10 and 83 for G 2 cultivars. Statistical analysis of the obtained data in the first season revealed that there are significant differences between T.C321 cultivars and the two other cultivars, F- value and L.S.D were 14.62 and 2.10, respectively. The three maize cultivars were classified into two groups according to infestation of aphids. First group (a) was represented by T.C321; second group (b) was occupied by S.C10 and G2.In the second season, 2017, the results took the same trend as in the first season (Table 1) and Fig.(1). The heaviest infestation of aphids was recorded on the maize plants of T.C321, with106.3 individuals/leaf followed significantly by 87.5 individuals/ leaf for S.C10 and 83.7 for G 2. Analysis of variance of the obtained data in the second season showed that there were significant differences between the studied maize cultivars as calculated by F- value and L.S.D with values 20.99 and 1.14, respectively. According to statistical analysis, the three studied maize cultivars could be arranged discerningly according to infestation of aphids, as follow: T.C $321>$ S.C10 > G2. The whole seasonal averages of aphids individuals counted in 2016 and 2017 altogether were 109.5, 85.2 and 83.3 individuals / leaf of T.C321, S.C10 and G2, respectively. Statistical analysis of the obtained data using $\quad F$ and L.S.D values indicated significant differences in the rate of infestation by Rhopalosphum maidis aphid to the tested cultivars in the two studied seasons where, F and L.S.D values were 18.34 and 1.17, respectively. The tested varieties could be divided into two groups, the high infested group was represented by T.C321, and the moderately infested group included S.C10 and G2 cultivars.

\section{Statistical analysis}


Table 1. Mean numbers of Rhopalosphum maidis per plant of three maize cultivars at Qalubia Governorate during two seasons of 2016 and 2017.

\begin{tabular}{|c|c|c|c|c|c|c|c|c|c|c|}
\hline \multirow{2}{*}{ Months } & \multirow{2}{*}{$\begin{array}{l}\text { Insp. } \\
\text { Date }\end{array}$} & \multicolumn{3}{|c|}{$1^{\text {st }}$ season $(2016)$} & \multicolumn{3}{|c|}{$2^{\text {nd }}$ season $(2017)$} & \multicolumn{3}{|c|}{ Mean of two seasons } \\
\hline & & G2 & $\begin{array}{c}\text { S.C } \\
10\end{array}$ & $\begin{array}{l}\text { T.C } \\
\mathbf{3 2 1}\end{array}$ & G2 & $\begin{array}{c}\text { S.C } \\
10\end{array}$ & T.C321 & G2 & S.C10 & T.C321 \\
\hline \multirow{4}{*}{ July } & $20 / 7$ & 2.4 & 1.9 & 1.6 & 1.7 & 2.1 & 2.1 & 2.05 & 2.00 & 1.85 \\
\hline & $26 / 7$ & 5.8 & 5.8 & 4.9 & 6 & 6.5 & 6.1 & 5.90 & 6.15 & 5.50 \\
\hline & $3 / 8$ & 6.9 & 6.4 & 7.6 & 7.1 & 7.3 & 7.1 & 7.0 & 6.85 & 7.35 \\
\hline & $10 / 8$ & 9.7 & 8.6 & 17 & 9.1 & 7.9 & 7.8 & 9.4 & 8.25 & 12.40 \\
\hline \multirow[t]{4}{*}{ August } & $15 / 8$ & 10.6 & 10.7 & 20.2 & 10.8 & 9.3 & 8.7 & 10.7 & 10 & 14.45 \\
\hline & $23 / 8$ & 17.1 & 14.2 & 23.6 & 16.9 & 11 & 22.2 & 17.0 & 12.6 & 22.90 \\
\hline & $3 / 9$ & 15.3 & 16.2 & 18.2 & 15.8 & 14.6 & 19.3 & 15.55 & 15.4 & 18.75 \\
\hline & $10 / 9$ & 8.1 & 8.4 & 7.9 & 8.5 & 18 & 16.7 & 8.3 & 13.2 & 12.30 \\
\hline \multirow[t]{2}{*}{ September } & $18 / 9$ & 4.4 & 6.4 & 7.4 & 4.9 & 7.5 & 11.2 & 4.65 & 6.95 & 9.30 \\
\hline & $26 / 9$ & 2.7 & 4.7 & 4.8 & 2.9 & 3.3 & 5.1 & 2.8 & 4.00 & 4.95 \\
\hline Total & & 83 & 83.3 & 113.2 & 83.7 & 87.5 & 106.3 & 83.35 & 85.4 & 109.75 \\
\hline Mean & & $8.3^{b}$ & $8.34^{\mathrm{b}}$ & $11.3^{\mathrm{a}}$ & $8.37^{b}$ & $8.75^{b}$ & $10.6^{\mathrm{a}}$ & $8.33^{b}$ & $8.52^{b}$ & $10.95^{\mathrm{a}}$ \\
\hline F-value & & & 14.62 & & & 20.99 & & & 18.34 & \\
\hline LSD at 0.05 & & & 2.1 & & & 1.14 & & & 1.17 & \\
\hline
\end{tabular}

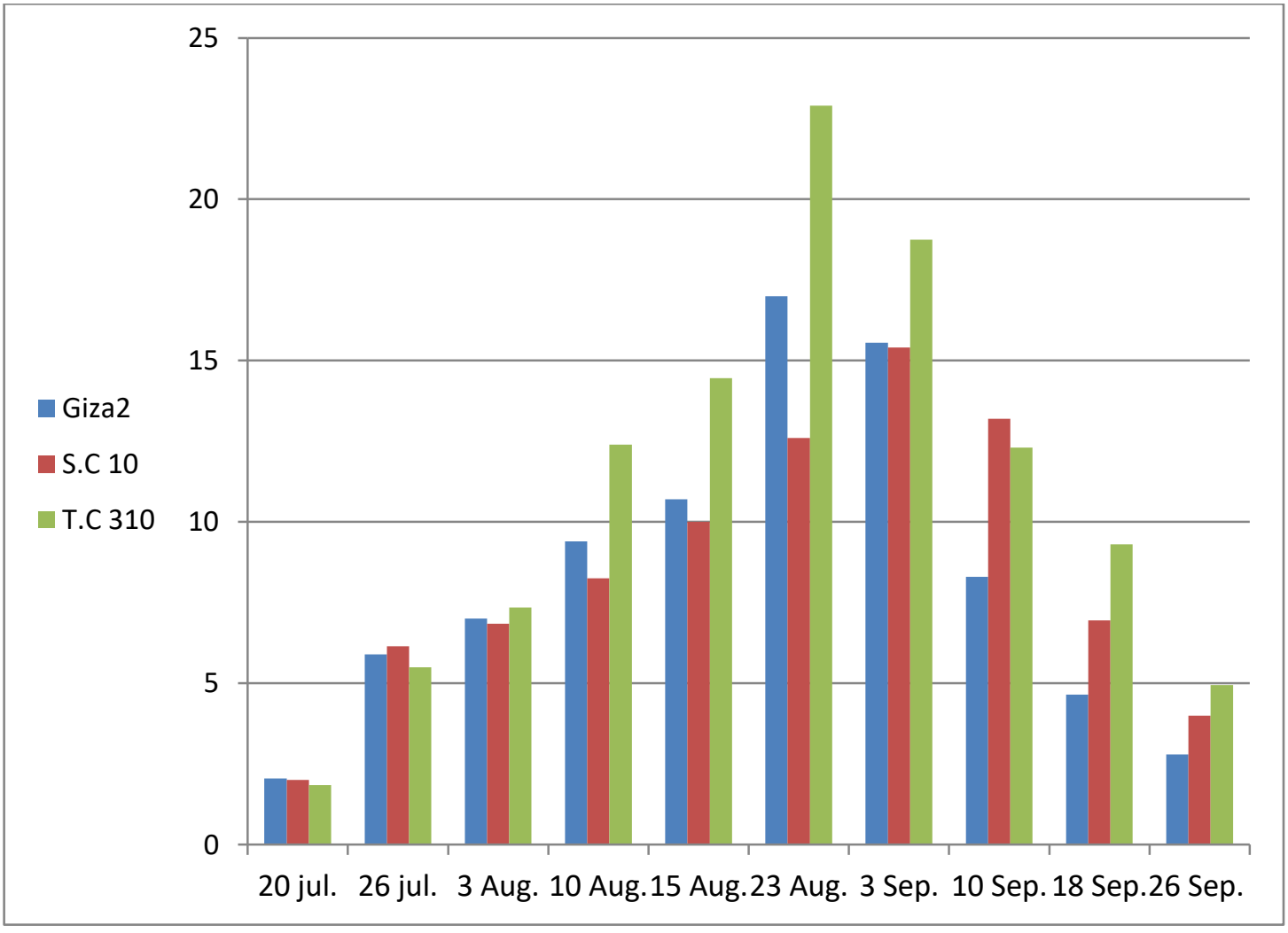

Fig (1): Mean number of (Rhopalosphum maidis) plant on three different maize during two seasons (2016) and (2017) 
1.2- Susceptibility of different maize cultivars to infestation with (Rhopalosiphum padi) during 2016 and 2017 seasons in Qalubia Governorate .

Results of mean number of aphids on different maize cultivars during two growing seasons of 2016 and 2017 were tabulated in Table (2)and Fig.(2). The obtained results indicated that there were significant differences between the tested maize cultivars in the infestation rates by aphids at the two studied seasons. Data showed no infestation by Rhopalosphum padi till the 2nd inspection count. The first appearance of aphid Rhopalosphum padi individual recorded at the first week of August on the three tested maize cultivars throughout two studied seasons. In the first growing season 2016, the seasonal mean number of this pest infesting leaves of maize cultivars, G2, S.C10 and T.C321, were $3.18,2.8$ and 3.02 individuals/ leaf, respectively.

Table 2. Mean numbers of Rhopalosphum Padi per plant on three maize cultivares at Qalubia Governorate during two seasons of 2016 and 2017.

\begin{tabular}{|c|c|c|c|c|c|c|c|c|c|c|}
\hline \multirow[b]{2}{*}{ Months } & \multirow{2}{*}{$\begin{array}{l}\text { Insp. } \\
\text { Date }\end{array}$} & \multicolumn{3}{|c|}{$1^{\text {st }}$ season $(2016)$} & \multicolumn{3}{|c|}{$2^{\text {nd }}$ season (2017) } & \multicolumn{3}{|c|}{ Mean of two seasons } \\
\hline & & G2 & $\begin{array}{c}\text { S.C } \\
10\end{array}$ & $\begin{array}{l}\text { T.C } \\
321\end{array}$ & G2 & $\begin{array}{c}\text { S.C } \\
10\end{array}$ & $\begin{array}{l}\text { T.C } \\
321\end{array}$ & G2 & $\begin{array}{c}\text { S.C } \\
10\end{array}$ & $\begin{array}{l}\text { T.C } \\
321\end{array}$ \\
\hline \multirow[b]{2}{*}{ July } & $20 / 7$ & $\mathbf{0}$ & $\mathbf{0}$ & $\mathbf{0}$ & $\mathbf{0}$ & $\mathbf{0}$ & $\mathbf{0}$ & $\mathbf{0}$ & $\mathbf{0}$ & $\mathbf{0}$ \\
\hline & $26 / 7$ & $\mathbf{0}$ & $\mathbf{0}$ & $\mathbf{0}$ & $\mathbf{0}$ & $\mathbf{0}$ & $\mathbf{0}$ & $\mathbf{0}$ & $\mathbf{0}$ & $\mathbf{0}$ \\
\hline \multirow{5}{*}{ August } & $3 / 8$ & 4 & 2.8 & 3.6 & 2.3 & 1.3 & 2.1 & 3.15 & 2.05 & 2.85 \\
\hline & $10 / 8$ & 5.2 & 4.9 & 5.2 & 4.1 & 3.3 & 4.9 & 4.65 & 4.1 & 5.05 \\
\hline & $15 / 8$ & 6.2 & 7.2 & 7.1 & 8.1 & 4.3 & 8.6 & 7.15 & 5.75 & 7.85 \\
\hline & $23 / 8$ & 8.2 & 6.7 & 5.9 & 8.6 & 5.9 & 5.5 & 8.4 & 6.3 & 5.7 \\
\hline & $3 / 9$ & 6 & 5.2 & 6.3 & 6 & 4.7 & 2.2 & 6 & 4.95 & 4.25 \\
\hline \multirow{3}{*}{ September } & $10 / 9$ & 2.2 & 1.2 & 2.1 & 1 & 1 & 1 & 1.6 & 1.1 & 1.55 \\
\hline & $18 / 9$ & $\mathbf{0}$ & $\mathbf{0}$ & $\mathbf{0}$ & 0 & $\mathbf{0}$ & $\mathbf{0}$ & 0 & 0 & 0 \\
\hline & $26 / 9$ & $\mathbf{0}$ & 0 & 0 & 0 & 0 & 0 & $\mathbf{0}$ & $\mathbf{0}$ & $\mathbf{0}$ \\
\hline Total & & 31.8 & 28 & 30.2 & 30.1 & 20.5 & 24.3 & 30.9 & 24.2 & 27.25 \\
\hline Mean & & $3.18^{\mathrm{a}}$ & $2.8^{\mathrm{a}}$ & $3.02^{\mathrm{a}}$ & $3.01^{\mathrm{a}}$ & $2.05^{b}$ & $2.4^{\mathrm{ab}}$ & $3.09^{a}$ & $2.43^{\mathrm{a}}$ & $2.73^{\mathrm{a}}$ \\
\hline F-value & & & 3.85 & & & 19.53 & & & 2.85 & \\
\hline $\begin{array}{c}\text { LSD at } \\
0.05\end{array}$ & & & 1.51 & & & 0.92 & & & 1.07 & \\
\hline
\end{tabular}

$\mathrm{a}, \mathrm{b} \& \mathrm{c}$ : There is no significant difference $(\mathrm{P}>0.05)$ between any two means, within the same column have the same superscript letter

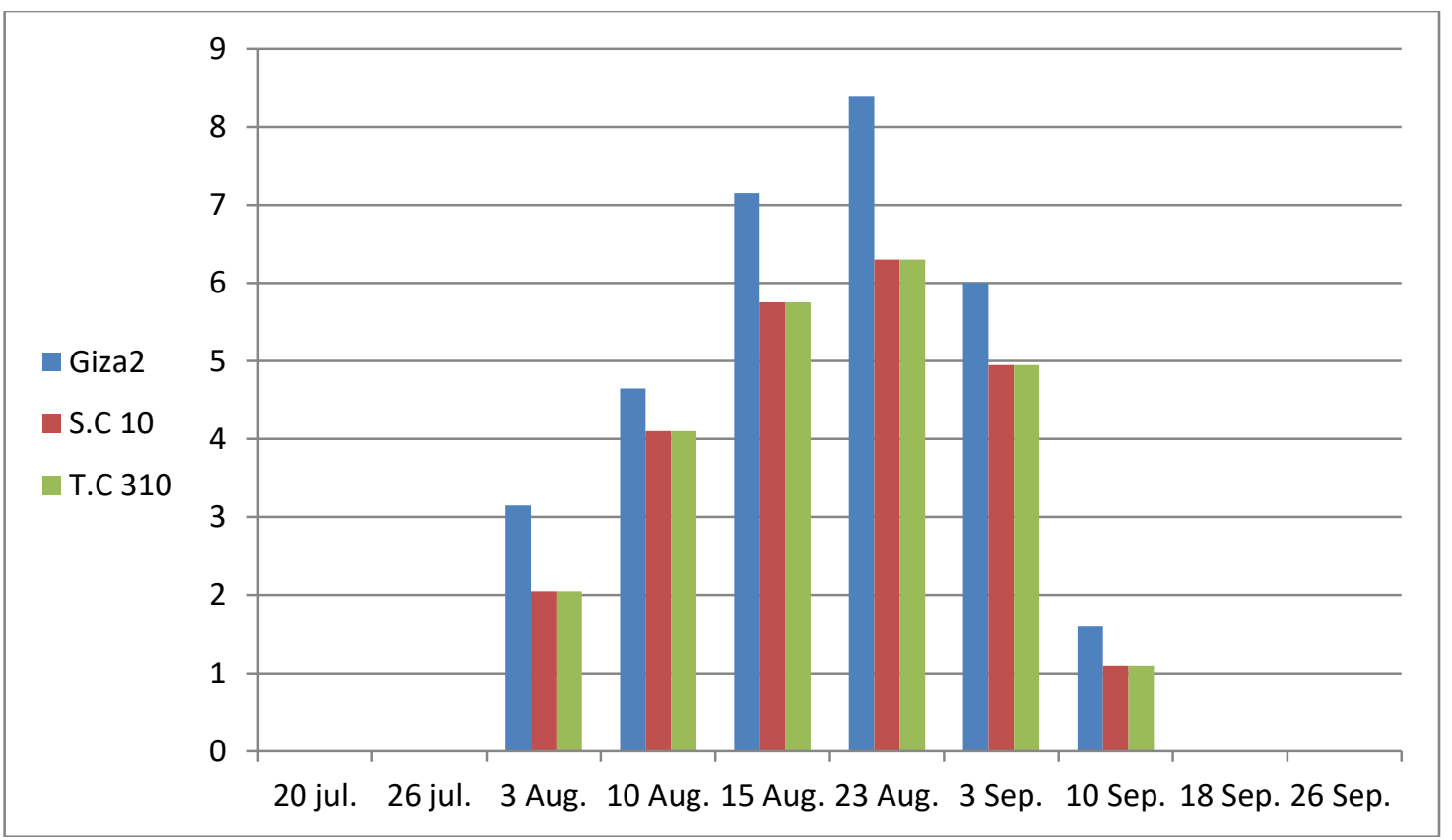

Fig (2): Mean number of (Rhopalosphum Padi) plant on three different maize during two seasons (2016) and (2017) 
The corresponding counts of aphids for the second tested growing season 2017 were 3.01, 2.05 and 2.4 individuals / leaf,, respectively. Regarding the general mean numbers of aphid counted on maize cultivars throughout the two investigated seasons together, the numbers of insects were 3.09, 2.43and 2.73 individuals/ leaf, respectively. Statistical Analysis in significant differences between the tested cultivars were obtained in the first season, as the tested cultivars occupied in the only one group. But in the second season, significant differenced recorded as $\mathrm{F}$ and L.S.D values were 19.53 and 0.92 respectively.

According to LSD values, the Susceptibility of different maize cultivars to infestation with (Rhopalosiphum padi could be arranged in three categories the first group (a) represented by $\mathrm{G} 2$ , the second group (b) contented the three remaining maize cultivars T.C 310 and the $3^{\text {th }}$ group (b) found that S.C10 cultivar( Table 2) and Fig.(2) .
2. Phytochemical analysis of different maize cultivars and its effect on infestation rate by aphid species.

Results in Tables (3 and 4) showed mean counts of examined insect pests aphids Rhopalosphum maidis and Rhopalosphum Padi infesting the maize cultivars, G2, S.C (10) and T.C (321, at the second growing season 2017 and their relation to the level of certain phytochemical components ( proteins, total carbohydrates, potassium, phosphorus, fiber ,VitB6 and VitB1) of the leaves of the concerned cultivars. The correlation coefficient factors between these components and the mean of population densities of the insect pests were also estimated.

\section{1.. Rhopalosphum maidis aphid.}

The simple correlation analysis in the changes of the population density of aphids in relation to the changes of seven different phytochemical leaves components of the three maize cultivars were tabulated in Table ( 3 ).

Table 3. Correlation coefficient factors between the population density of aphid (Rhopalosiphum maidis) and certain phytochemical components $(\mathrm{m} \mathrm{g} / 100 \mathrm{~g})$ of three maize cultivars during 2017 season at Qalubia Governorate .

\begin{tabular}{|c|c|c|c|c|c|c|c|c|}
\hline \multirow[b]{2}{*}{ Cultivars } & \multirow{2}{*}{$\begin{array}{c}\text { Population } \\
\text { density(mean) }\end{array}$} & \multicolumn{7}{|c|}{ Correlation coefficient factors } \\
\hline & & Protein & Car. & $\mathbf{K}$ & $\mathbf{P}$ & Fiber & VitB6 & VitB1 \\
\hline G (2) & $8.37^{b}$ & 10.9 & 33.1 & 287 & 201 & 7.3 & 0.289 & $\mathbf{0 . 3 3 7}$ \\
\hline S.C (10) & $8.75^{b}$ & 11.3 & 27.5 & 254 & 223 & 6.9 & 0.310 & 0.385 \\
\hline T.C321 & $10.6^{\mathrm{a}}$ & 12.9 & 23.2 & 230 & 241 & 6.2 & 0.403 & 0.450 \\
\hline $\mathbf{R}$ & & -0.767 & 0.959 & 0.963 & -0.95 & 0.868 & -0.76 & -0.90 \\
\hline $\mathbf{P}$ & & 0.444 & 0.183 & 0.174 & 0.195 & 0.331 & 0.454 & 0.287 \\
\hline
\end{tabular}

a, b \& c: There is no significant difference $(\mathrm{P}>0.05)$ between any two means, within the same column have the same superscript letter

a)Giza (2) cultivar:

Leaves of $\mathrm{G} 2$ cultivars which infested by the lowest seasonal mean number of aphid (8.37 individuals/ leaf,) contained the highest amount of potassium and fiber which play an important role in reducing the infestation rate of aphids were 287 and $7.3 \mathrm{mg} / 100 \mathrm{~g}$, respectively and also contained the highest amount of total carbohydrate $33.1 \mathrm{mg} / 100 \mathrm{~g}$. This cultivars showed the lowest rate of total protein (10.9), VitB6 and VitB1 were 0.289 and $0.337 \mathrm{mg} / 100$ $\mathrm{g}$, respectively.

\section{b) S.C10 cultivar:}

S.C10 cultivar which occupied as the second infested cultivar had found a moderate amount of $\mathrm{T}$. proteins was $11.3 \mathrm{mg} / 100 \mathrm{~g}$, carbohydrate (27.5), K (254), $\mathrm{P}$ (223), fiber
(6.9), VitB6 (0.310) and VitB1(0.385) (mg/100 g). Data showed that negative correlation between mean number of this pest with total protein, phosphor, VitB6 and VitB1which recorded $11.3,254,0.310$ and $0.385(\mathrm{mg} / 100 \mathrm{~g})$,, respectively and recorded positive correlation with carbohydrate, potassium and fibers in maize leaf $0.959,0.963$ and $0.868,(\mathrm{mg} / 100 \mathrm{~g})$, respectively.

\section{c). T.C (321) cultivar:}

It infested by the highest number of aphides (10.6 individuals/ leaf) contained the highest amount of total protein, phosphorus,VitB6 and VitB1 were 12.9, $241,0.403$ and $0.450(\mathrm{mg} / 100 \mathrm{~g})$, respectively. On the other hand, this cultivars contained the lowest amount of total carbohydrates, potassium 
and fiber were $23.2,230$ and $6.2 \mathrm{mg} / 100 \mathrm{~g}$. The highest infestation of T.C 321 cultivars may be attributed to the lack of potassium and fiber. Potassium can be play an important role in increasing the thickness of cell walls of the plant and lead to reduce the infestation with the most pests and fiber which considered as article repellent to insect infestation.

\section{Rhopalosiphum padi aphid .}

From data tabulated in Table (4), it could be noticed that the infestation degree with the aphid Rhopalosphum padi to maize plants belonging to the three cultivars to the changes of seven different phytochemical leaf components . The analysis of variance indicated significant differences among the leaves of the three cultivars in their amount of contents (total proteins, total carbohydrates, phosphorus, potassium, fiber, VitB6 and VitB1).

Table 4. Correlation coefficient factors between the population density of aphids (Rhopalosiphum padi) and phytochemical components of three maize cultivars during 2017 season at Qalubia Governorate

\begin{tabular}{ccccccccc}
\hline \multirow{2}{*}{ Cultivars } & $\begin{array}{c}\text { Population } \\
\text { density(mean) }\end{array}$ & \multicolumn{8}{c}{ Correlation coefficient factors } \\
\cline { 3 - 9 } & & Protein & Car. & K & P & Fiber & VitB6 & VitB1 \\
\hline G (2) & $\mathbf{3 . 0 1}^{\text {a }}$ & $\mathbf{1 0 . 9}$ & $\mathbf{3 3 . 1}$ & 287 & $\mathbf{2 0 1}$ & $\mathbf{7 . 3}$ & $\mathbf{0 . 2 8 9}$ & $\mathbf{0 . 3 3 7}$ \\
S.C (10) & $\mathbf{2 . 0 5}^{\text {b }}$ & 11.3 & 27.5 & 254 & $\mathbf{2 2 3}$ & $\mathbf{6 . 9}$ & $\mathbf{0 . 3 1 0}$ & $\mathbf{0 . 3 8 5}$ \\
T.C 321 & $\mathbf{2 . 4 3}^{\text {ab }}$ & 12.9 & 23.2 & 230 & $\mathbf{2 4 1}$ & $\mathbf{6 . 2}$ & $\mathbf{0 . 4 0 3}$ & $\mathbf{0 . 4 5 0}$ \\
R & & $\mathbf{0 . 6 6 7}$ & $\mathbf{0 . 8 3 8}$ & $-\mathbf{- 0 . 7 2}$ & $\mathbf{0 . 5 5 3}$ & $\mathbf{- 0 . 5 3}$ & $\mathbf{- 0 . 5 4}$ & $\mathbf{0 . 8 2 9}$ \\
P & & 0.535 & $\mathbf{0 . 3 6 8}$ & $\mathbf{0 . 4 9 1}$ & $\mathbf{0 . 6 2 7}$ & $\mathbf{0 . 6 4 8}$ & $\mathbf{0 . 6 3 9}$ & $\mathbf{0 . 3 7 8}$ \\
\hline
\end{tabular}

a, $b$ \& c: There is no significant difference $(\mathrm{P}>0.05)$ between any two means, within the same column have the same superscript letter

a).Giza (2) cultivar :

Giza (2) cultivar which infested by the highest number of Rhopalosiphum padi (3.01 individual/ leaf) contained the highest amount of total carbohydrates, potassium and fiber were 33.1, 287 and 7.3, mg/100 g, respectively). On the other hand, this cultivars contained the lowest amount of total protein, phosphorus, VitB6 and VitB1 were 10.9, 201, 0.289 and $0.337 \mathrm{mg} / 100 \mathrm{~g}$, respectively.

\section{b) S.C(10) cultivar :}

S.C10 cultivar which infested by the lowest seasonal mean number of aphids (2.05 individual/ leaf) contained moderate rate of total protein, total carbohydrates, potassium, phosphorus, fiber, VitB6 and VitB1 were 11.3 , $27.5,254,223,6.9,0.310$ and $0.385 \mathrm{mg} / 100$ $\mathrm{g}$, respectively.

\section{c) T.C 321 cultivar:}

T.C 321 cultivar which infested by average number of aphids (2.43 individual/ leaf) contained the highest amount of total protein, phosphorus, VitB6 and VitB1 were 12.9, 241 , 0.403 and 0.450 , respectively, On the other hand, this cultivars contained the lowest amount of total carbohydrates, potassium and fiber recorded $23.2,230$ and $6.2, \mathrm{mg} / 100 \mathrm{~g}$, respectively. T.C (321) cultivar contained the lowest amount of potassium was $230 \mathrm{mg} / 100 \mathrm{~g}$. The highest infestation of T.C321 cultivar may be attributed to the lack of potassium . Potassium can be play an important role in increasing the thickness of cell walls of the plant and lead to reduce the infestation with the most pests .

Data showed that positive correlation between mean number of this pest with total protein, phosphorus, VitB6 and VitB1which recorded $0.667,0.553,-053$ and $0.829(\mathrm{mg} / 100$ g), respectively and recorded negative correlation with potassium and fibers in maize leaf -0.72 and $\quad-0.53(\mathrm{mg} / 100 \mathrm{~g})$, respectively. The relationship between. Phytochemical analysis of different maize cultivars and its effect on infestation rate by aphid species was studied by Eisenring et al. (2018) mentioned that phytochemical defense responses of plants are often herbivore-specific and can be affected by a herbivore's feeding mode. However, comprehensive studies documenting the impact of multiple herbivores from different feeding guilds on induced phytochemical responses in distal leaves and its consequences for plantmediated herbivore interactions are limited and findings are inconsistent. The results obtained that aphids decreased salicylic acid levels while 
whitefly-infested plants contained increased ABA levels. In general, feeding mode of a herbivore can affect systemically induced changes in phytochemistry and plant-mediated indirect interactions even though the two phloem-feeding herbivores triggered different phytohormonal responses.

3. Anatomical characters of three maize cultivar leaves and their effect on infestation rate by aphid species .

One of the most important factors which explained the degree susceptibility of the previously mentioned maize cultivars to infestation by aphids insects is the effect of anatomical characters. This part of study was done to discover the correlation between the tested layers and the population density of insects for the three studied maize cultivars at season 2017. The relation between the thickness of each layer and the population density of certain aphid insect pests can be explained as follows:

\subsection{Rhopalosiphum maidis :}

From the data presented in Table (5) and Fig3 (A, B and C), the simple correlation test between the mean numbers of aphid nymphs on leaves of the three tested cultivars and the thickness of the different layers of the leaf were either positive or negative but insignificant. The correlation coefficient values were insignificantly positive between the mean abundance of aphid nymphs infesting different cultivars in relation to thickness of xylem in vascular bundle. $(\mathrm{r}=0.910 \mu \mathrm{m})$ and were insignificantly negative with upper and lower epidermal cuticle thickness (-0.58 and -0.095 $\mu \mathrm{m})$ respectively.

The same was recorded in No. of spongy tissue layers in the blade, spongy tissue thickness in the blade, No. of spongy tissue layers in midrib of leaf, spongy tissue thickness midrib of leaf, thickness of fibers and above the upper epidermis at midrib were $(r=0.995$,$0.983,-0.580,-0.105,-0.580,-0.083,-0.651 \mu \mathrm{m}$, respectively. The correlation coefficient values were insignificantly negative in thickness of fibers around the large vascular bundle , thickness of phloem in large vascular bundle and thickness of widest xylem vessel in vascular bundle were ( $\mathrm{r}==-0.995,-0.690-0.927 \mu \mathrm{m}$, respectively). Although there was no distinct correlation, it was observed that Giza 2 cultivar was the most susceptible to the infestation being (3.0.1 individual / leaf,), which had the thinnest layers of upper epidermal cuticle thickness, upper epidermal thickness, lower pidermal cuticle thickness, No. of spongy tissue layers in the blade, thickness of fibers above the upper epidermis at midrib, thickness of fibers around the large vascular bundle, thickness of phloem in large vascular bundle and thickness of widest xylem vessel in vascular bundle $(9.00,25.20$, $18.00,4.00,63.00,13.00,45.00$ and $27.00 \mu \mathrm{m}$, respectively), and also average of lower epidermal cuticle thickness, spongy tissue thickness in the blade, No. of spongy tissue layers in midrib of leaf and spongy tissue thickness midrib of leaf $(8.10,437.40,10.00$ and $1093.50 \mu \mathrm{m}$, respectively).

On the contrary by cultivar S.C (10), 2.05 nymph/leaflet which is characterized by the thickest layer of upper epidermal cuticle thickness, lower epidermal cuticle thickness, upper epidermal thickness, lower epidermal cuticle thickness, No. of spongy tissue layers in the blade, spongy tissue thickness in the blade. spongy tissue thickness midrib of leaf, thickness of fibers around the large vascular bundle, thickness of phloem in large vascular bundle and thickness of widest xylem vessel in vascular bundle were 12.60, 9.00, 27.00, 24.30, 5.00, $554.85,1242.00,22.50,58.50$ and $54.00 \mu \mathrm{m}$ respectively. 


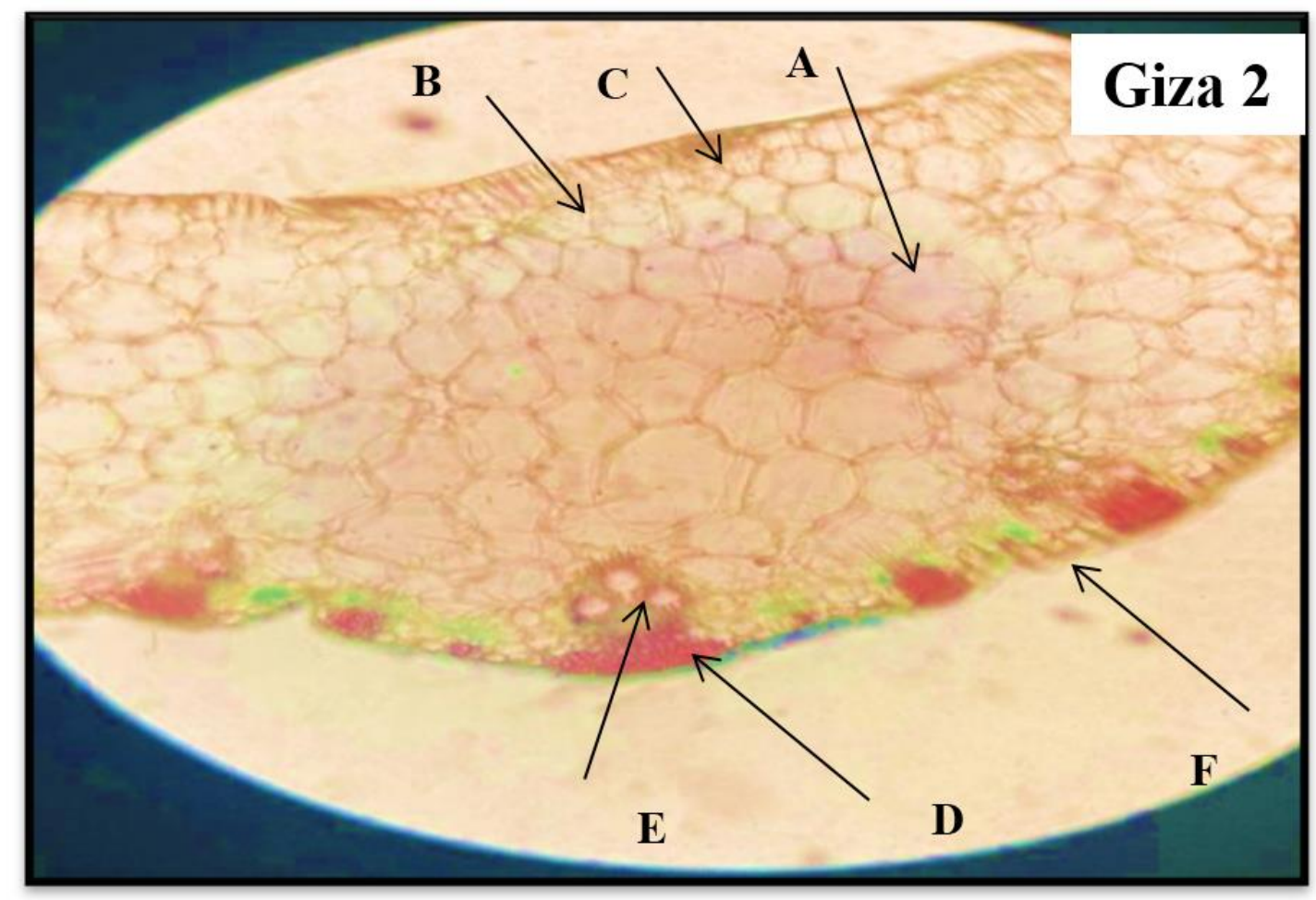

Fig.3 (a): Light micrograph of maize cultivar Giza 2 leave cross section, A= Spongy layer $\quad B=$ Upper epidermis $\quad C=$ Upper cuticle $\mathrm{D}=$ Xylem $\quad \mathrm{E}=$ Phloem $\quad \mathrm{F}=$ Lower epidermis

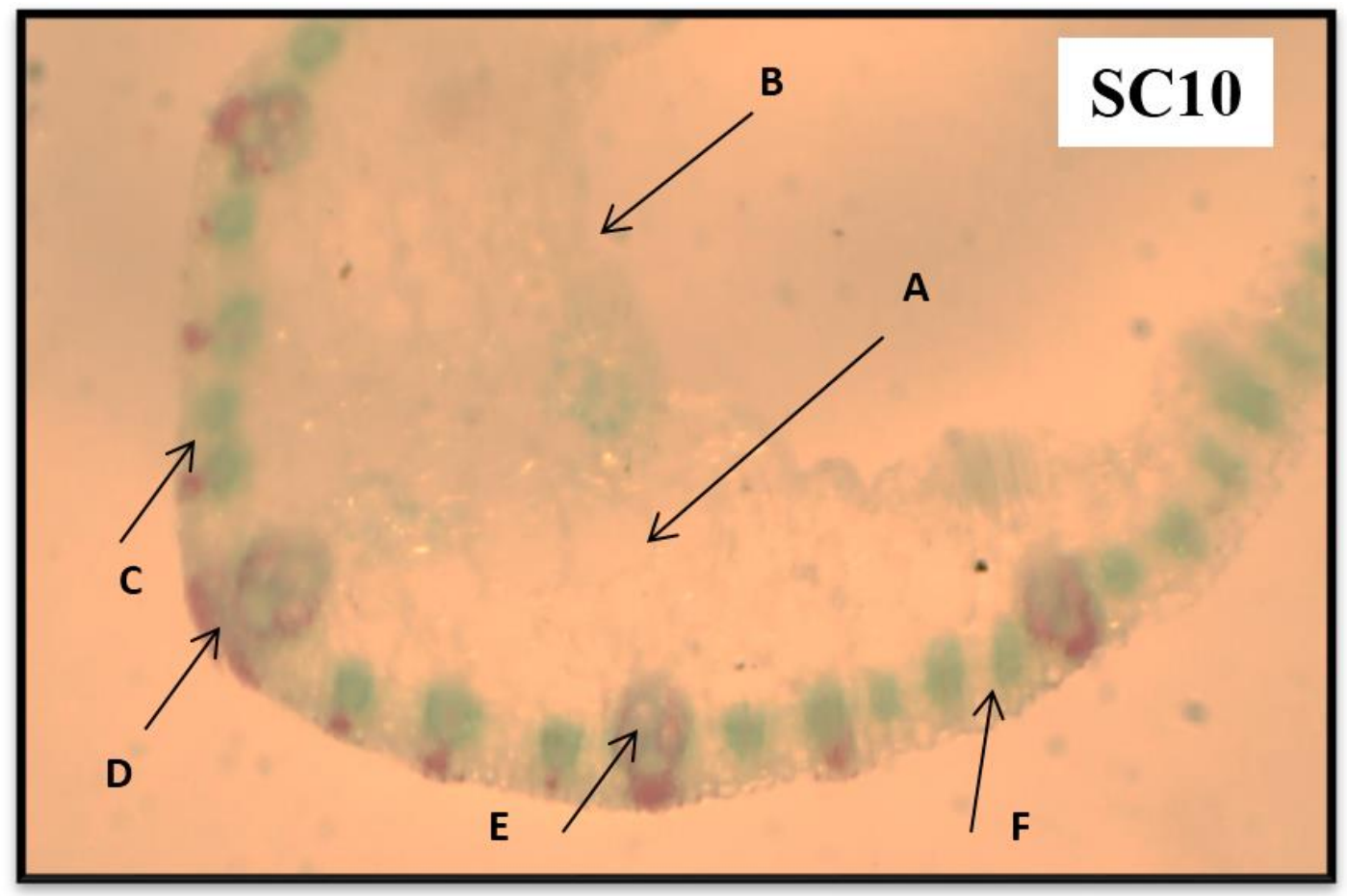

Fig 3 (B): Light micrograph of maize cultivar SC10 leave cross section,

$\begin{array}{ccc}\begin{array}{c}\text { A=Spongy layer } \\ \text { D=Xylem }\end{array} & \mathbf{B}=\text { Upper epidermis } & \mathbf{C}=\text { Upper cuticle } \\ \mathrm{E}=\text { Phloem } & \mathbf{F}=\text { Lower epidermis }\end{array}$




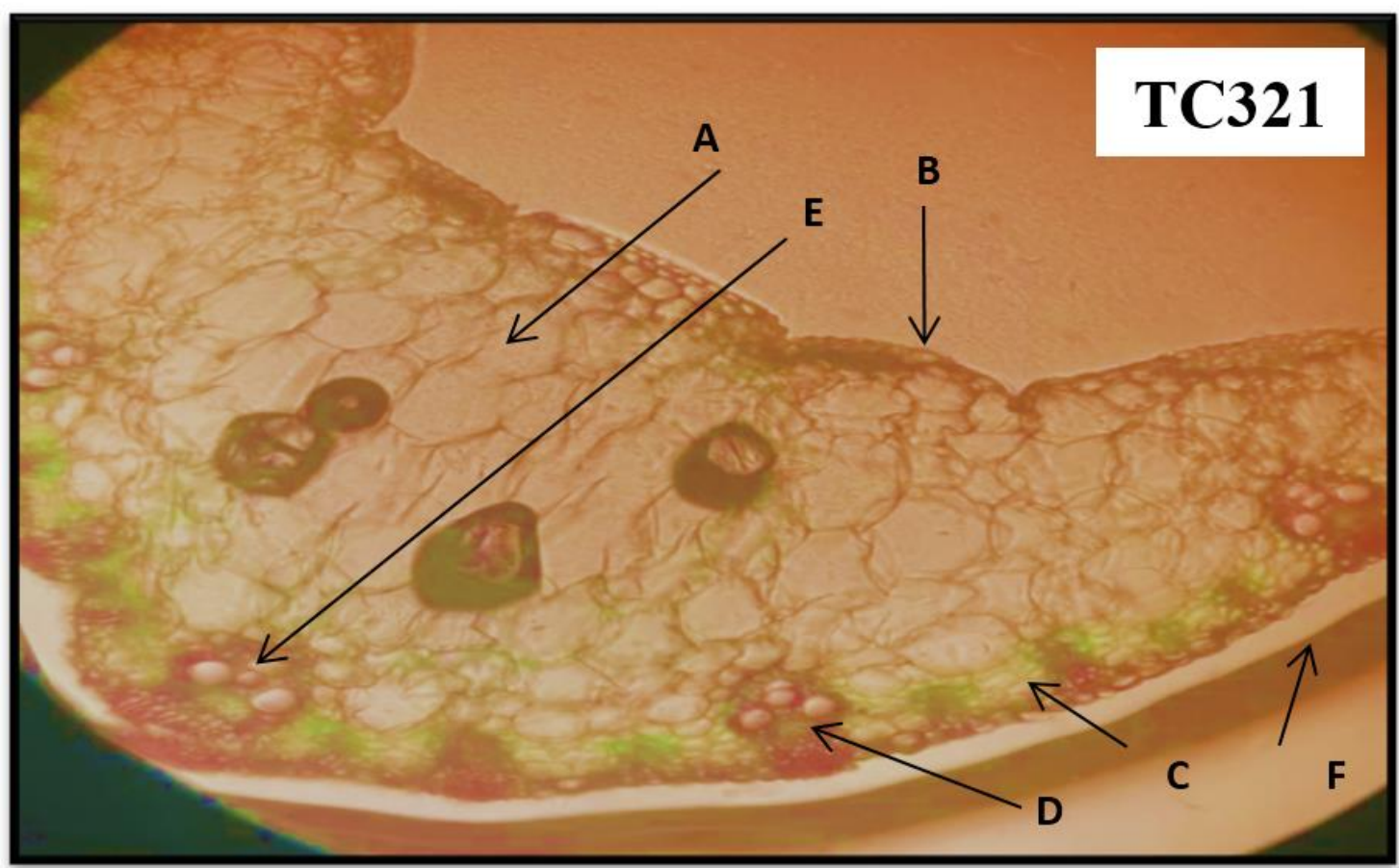

Fig 3 (C): Light micrograph of maize cultivar TC321 leave cross section, A= Spongy

layer $\quad B=$ Upper epidermis $\quad C=$ Upper cuticle

$\mathrm{D}=$ Xylem $\quad \mathrm{E}=$ Phloem

\subsection{Rhopalosiphum padi}

The seasonal mean counts of aphids infesting leaves of the three maize cultivars were tabulated in Table (5) and Fig. 3( A, B and C) with the mean thickness of leaf layers of these cultivars and their correlation. A significant difference between the mean count of aphids harbored on leaves of the three tested cultivars was found, as the heaviest infestation was recorded on leaves of T.C321 cultivar (10.6 individuals / leaf) which had the thinnest layers of the upper and lower epidermal cuticle thickness , No. of spongy tissue layers in the blade, spongy tissue thickness in the blade and spongy tissue thickness midrib of leaf. (9.00, $7.20,4.00,324.00$ and $810.00 \mu \mathrm{m}$, respectively), and also average of upper epidermal thickness, lower epidermal thickness, thickness of phloem in large vascular bundle, thickness of xylem in vascular bundle and thickness of widest xylem vessel in vascular bundle $(27.00,22.50,49.50,99.00$ and $45.00 \mu \mathrm{m}$, respectively), as the lowest infestation was recorded . on leaves of Giza (2) cultivar (8.37 individuals/ leaf,) which had the thinnest larger of the upper and lower epidermal cuticle thickness, upper and lower epidermal thickness, No. of spongy tissue layers in the blade, Spongy tissue thickness in the blade, spongy tissue thickness midrib of leaf, thickness of fibers around the large vascular bundle, thickness of phloem in large vascular bundle and thickness of widest xylem vessel in vascular bundle. (12.60, 9.00, 27.00, 24.00, 5.00, 554.85, $1242.00, \quad 22.50, \quad 58.50$ and $54.00 \mu \mathrm{m}$, respectively). On the other hand, the other one species were average in the aphids infection and were therefore average in the thickness of the layers , S.C (10) were the injury rate (8.75) and therefore were the upper and lower epidermal cuticle thickness, No. of spongy tissue layers in the blade, spongy tissue thickness in the blade, spongy tissue thickness midrib of leaf and thickness of fibers above the upper epidermis at midrib $(9.00,8.10,4.00,437.40,1093.50$ and $63.00, \mu \mathrm{m}$ respectively.

The correlation coefficient values was negative with (thickness of fibers above the upper epidermis at midrib, thickness of phloem in large vascular bundle and thickness of xylem in vascular bundle were $-0.083,-0.030$ and $0.935 \mu \mathrm{m}$, respectively while was positive with upper epidermal cuticle thickness, lower epidermal cuticle thickness. upper epidermal thickness, lower epidermal cuticle thickness, No. of spongy tissue layers in the blade, spongy tissue thickness in the blade .

No. of spongy tissue layers in midrib of leaf, spongy tissue thickness midrib of leaf, thickness of fibers around the large vascular bundle and thickness of widest xylem vessel in vascular bundle were $0.987,0.775,0.632,0.822,0.987$, $0.782,0.987,0.651,0.032$ and $0.851 \mu \mathrm{m}$, respectively. 
Table 5. Relation between leaf layers thickness of three maize cultivars and aphid (Rhopalosiphum maidis) infestation throughout second season 2017 Qalubia governorate. Leaf layers

\begin{tabular}{|c|c|c|c|c|c|c|c|c|c|c|c|c|c|c|}
\hline \multirow[b]{2}{*}{ } & \multirow[b]{2}{*}{$\underset{\Sigma}{\tilde{E}}$} & \\
\hline & & 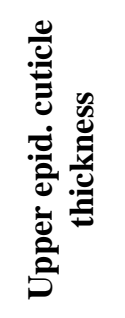 & 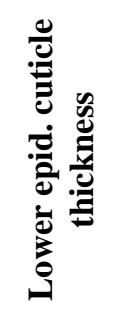 & 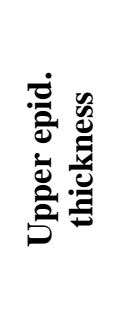 & 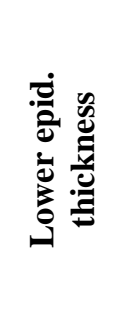 & 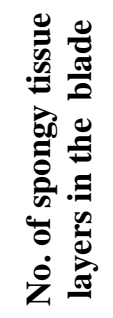 & 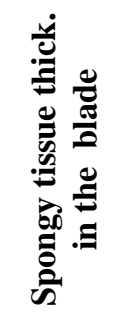 & 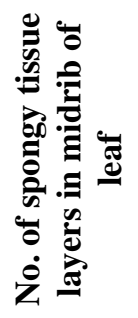 & 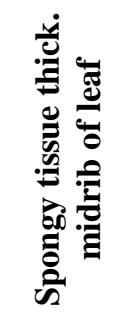 & 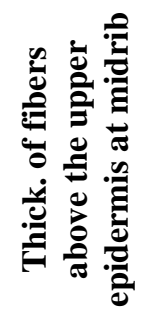 & 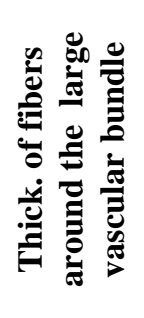 & 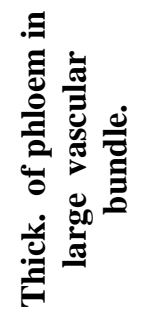 & 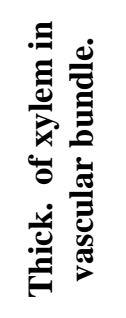 & 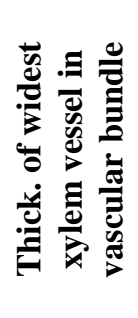 \\
\hline S.C (10) & $2.05^{b}$ & 12.60 & 9.00 & 27.00 & 24.30 & 5.00 & $\mathbf{5 5 4 . 8 5}$ & 10.00 & 1242.00 & 72.00 & 22.50 & 58.50 & 90.00 & 54.00 \\
\hline Giza (2) & $3.01^{\mathrm{a}}$ & 9.00 & 8.10 & 25.20 & 18.00 & 4.00 & 437.40 & 10.00 & 1093.50 & 63.00 & 13.50 & 45.00 & 108.00 & 27.00 \\
\hline T.C (310) & $2.43^{\mathrm{ab}}$ & 9.00 & 7.20 & 27.00 & 22.50 & 4.00 & 324.00 & 14.00 & 810.00 & 94.50 & 22.50 & 49.50 & 99.00 & 45.00 \\
\hline $\mathbf{R}$ & & -0.580 & -0.095 & -0.995 & -0.983 & -0.580 & -0.105 & -0.580 & -0.083 & -0.651 & -0.995 & -0.690 & 0.910 & -0.927 \\
\hline $\mathbf{P}$ & & 0.606 & 0.939 & 0.061 & 0.118 & 0.606 & 0.933 & 0.606 & 0.947 & 0.548 & 0.061 & 0.515 & 0.273 & 0.152 \\
\hline
\end{tabular}


Table 6. Relation between leaf layers thickness of three maize cultivar and aphid (Rhopalosiphum padi) infestation throughout second season 2017 Qalubia governorate.

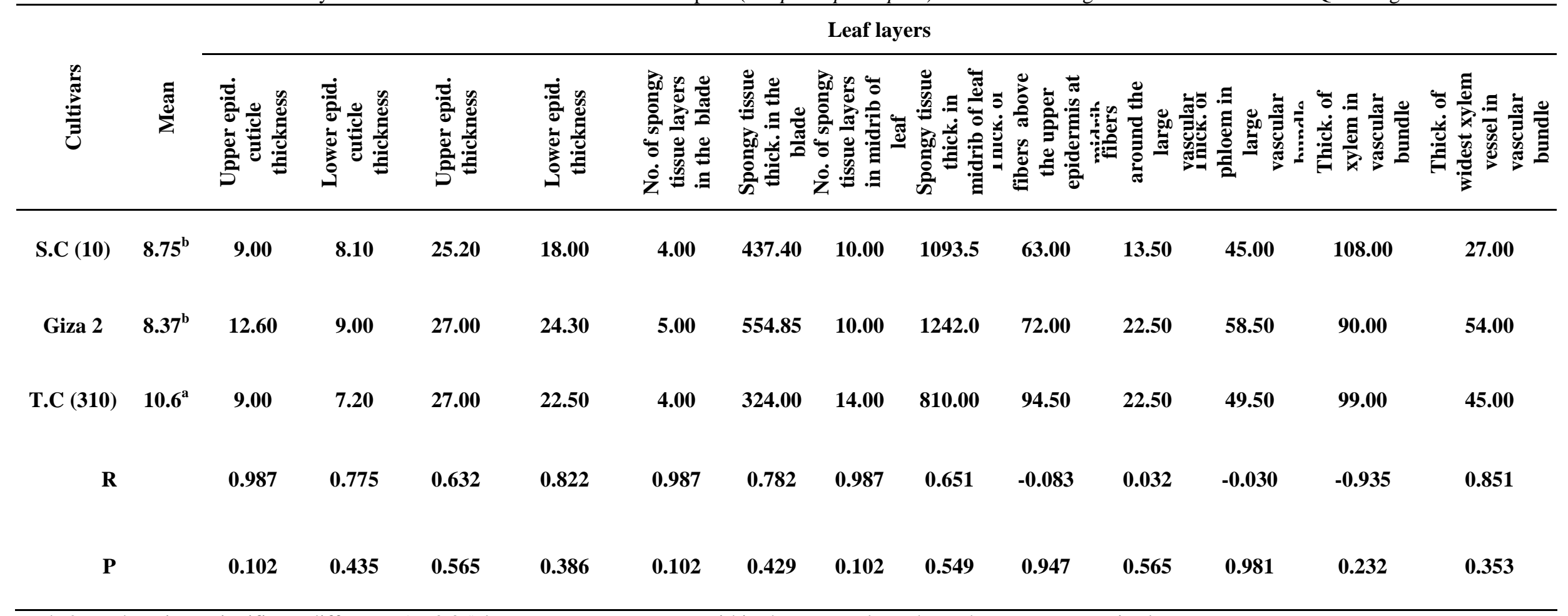

a, b \& c: There is no significant difference ( $\mathrm{P}>0.05)$ between any two means, within the same column have the same superscript letter 


\section{References}

Abd el Fatah, H. Y. ;Mohamed,E. A.; Al-Din Hassan, M. B. and Mohamed, K.A 2015. An Economic Analysis for Maize Market in Egyp.t Middle East Journal of Agriculture Research Volume : 04 . 873-878

Ali, N. A. H. (2004): Seasonal activities of legumes aphid, Aphis craccivora Koch (Homoptera: Aphididae), on faba bean cultivars in Upper Egypt and its effects on growth and yield. Alexandria, Journal of Agriculture Research, 49(2):87-92.

Ali, Sh. A. M.; Saleh, A. A. A. and Mohamed, N. E. 2013. Aphis craccivora Koch. and predators on Faba bean and cowpea in newly reclaimed areas in Egypt. Egyptian Journal of Agriculture Research, 91 (4): 1423-1438.

Amin, T. R. and El-Halafawy, N. A. 2001. Sodium and potassium ions content of hemolymph in the mormal and starved cotton leaf worm, Spodoptera littoralis (Boisd). Bull. Ent. Soc. Egypt, Econ.Ser.28: 49-57.

Eisenring, M.; Glauser, G.; Meissle,M. and Romeis, J. 2018. Differential Impact of Herbivores from Three Feeding Guilds on Systemic Secondary Metabolite Induction, Phytohormone Levels and Plant-Mediated Herbivore Interactions. Chem Ecol. 2018 Dec;44(12):1178-1189.

El-Defrawi, G. M.; Emam, A. K.; Marzouk, I. A. and Rizkalla, L. 2000. Population dynamics and seasonal distribution of Aphis craccivora Koch and associated natural enemies in relation to virus disease incidence in faba bean fields. Egyptian Journal of Agriculture Research, 78(2):627-641.

El-Fatih, M.M.; Moharum, F. A. and Ahmed, M.A.2015. First record of the mealybug, Phenacoccus. solenopsis Tinsley (Hemiptera: Pseudococcidae) as a new insect pest on banana plants in Egypt. J. Plant Prot. and Path., 6 (11): $1537-1541$
El - Gindy, M. A., 2002. Studies on certain homopterous insect vectors of plant pathogenic diseases. Ph. D. Thesis, Fac. Agric. Zagazig Univ., $274 \mathrm{pp}$.

Fisher, R. A. 1954.: Statistical methods for research worken. Oliver and Boyed. Edinburgh, London, 354pp.

Hassan Flayiah Hassan, 2012. Constructed model of cost/Bonefit Analysis strategy for stem corn borer Sesamia cretica Led. Journal of Agricultural Science and Technology, 2;138-142

Ibraheem M. H. 2021. Ecologial and biological studies on aphids and their associated predarory spiders on two field crops at Qalubyia governorate, Egypt. Ph. D Thesis, Fac. of Sci., Ain-Shams Univ.

Ismail, I. I.; Semeada, A. M., and Abd El-Salam, S. A. 1993. Seasonal occurrence and host range of the corn leaf aphid, Rhopalosiphum maidis Fitch at Giza and Qalubia Governorates. Bulletin of the Entomological Society of Egypt. 71:33-40.

Jackson, M. L. 1973. Soil chemical analysis. Prentic-Hall of India-Private, New Delhi, pp.: 144-197

Maini and Burgio 1999 ; Colorimetric method for determination of sugars and related substances .Analytical Chemistry, 28(3): 302-307.

Pregl, F. 1945. Quantitative organic microanalysis 4thed. J. andA.Chundril 4th .London.94-101.

Swaminathan, R.; Meena, A. and Meena, B. M. 2016. Diversity and predation potential of major aphidophagous predators in maize. Applied Ecological and Environmental Research, 13(4):1069-1084

Troug ,E.;and Meyer .A.H. 1939. Improvement in deiness colorimetric for phosphorus and arsenic .Ind. Eng. Chen.Ann.Ed.,1:136-139.

Walker, R.A. and Duncan, D.B. 1969. A Bayea rule for the symmetric multiple compartision problem. Amer. Statist. Assoc. J. Dec. 1485-1503 


\section{حساسية بعض أصناف الأرة للأصابة بنوعين من حشرات من الأرة فى محافظة القليوبية منى عصام حسن 1 ، عزت فرج الخياط²، صفاء محمود حلاوه2 2

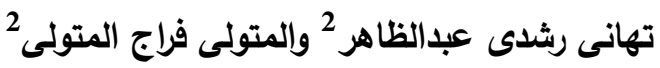 1- - بمعه بحوث وقاية النباتات - مركز البحوث الزراعية 2- قسم وقاية النبات -كلية الزراعة - جامعة بنهات وباته}

تم أجراء دراسات حقلية ومعملية فى خلال موسمين متتالين (2016 و 2017) لدراسة قابلية ثلاث أصناف من الذرة جيزة (2) ، الهجين الفردى (10) ، الهجين الثلاثي (321) للإصابة. بنوعين من حشرات المن ، Rhopalosiphum maidis و Rhopalosiphum padi. وقد أظهرت النتائج فروق معنوية في قابلية أصناف الذرة للإصابة بالمن يث وجد أن كلا من الصنف جيزة (2) وهجين فردى (10) كانا الأقل إصابة بكلا نوعى المن ، ومن ناحية أخرى كان الصنف هجين ثلاثى 321هو الأكثر إصابة ، وأظهر التحليل الكيميائي للأوراق الأصناف الدرروسة خلال موسم النمو لعام 2017 مثل البوتاسيوم ، والمحتوى البروتينى والكربوهيدرات والفوسفور وكذلك الألياف ومحتوى

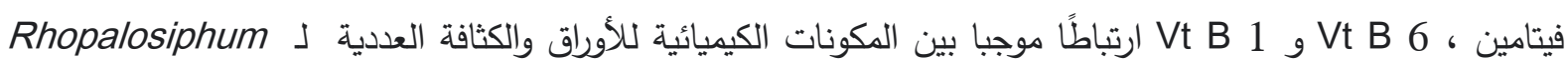
maidis على أوراق الأصناف الثلاثة المختبرة ، حيث تم تسجيل أكبر إصابة على أوراق الصنف هجين ثلاثى بعدد (10.6) فرد / ورقة) والتي كانت ذات طبقات نحيفة من الطبقة العليا والسفلى من البشرة. سمك البشرة، عدد طبقات الأنسجة الإسفنجية في النصل ، سماكة الأنسة الإسفنجية في النصل وسمك الأنسجة الإسفنجية الوسطى من الورقة. (9.00 ، 7.20 ، 4.00 ، 324.00 و 810.00 ميكرومتر ، على التوالي) . 